\title{
Co-creation: moving towards a framework for creating innovation in the Triple Helix
}

\section{T. Hughes}

Faculty of Business \& Law, University of the West of England, Bristol, UK

\begin{abstract}
:
The objective of the paper is to demonstrate how the theoretical ideas of Service-Dominant Logic (S$D$ logic) can usefully be applied to innovation through collaboration between university, industry and government. The debate around S-D logic has stimulated much discussion around three areas that are particularly pertinent in considering the co-creation of knowledge within the Triple Helix. The first area relates to understanding the nature of the resources provided by all the parties involved and the process through which they are integrated. The second area relates to interaction between the parties involved. The third and most complex area relates to how value is perceived by the different parties. This discussion leads to a proposed model of the co-creation process and four suggested research agendas: Research Agenda One, relating to the resources supplied by the parties and their integration; Research Agenda Two, concerning the interaction practices that enhance co-creation; Research Agenda Three, exploring what value propositions will motivate the different parties to cocreate; and Research Agenda Four, considering how co-creation modifies the resources of the parties involved. A model of the co-creation process that encompasses these four research agendas and provides a conceptual framework to analyse Triple Helix initiatives is proposed. Some practical implications are then discussed, relating to the challenges for researchers in identifying who to cocreate with and understanding what value propositions will motivate potential partners.
\end{abstract}

Email: tim.hughes@uwe.ac.uk 


\section{Co-creation: moving towards a framework for creating innovation in the Triple Helix}

\section{Introduction}

The applied nature of the Triple Helix model implies the importance of collaboration and cocreation between a range of stakeholders in the process of identifying what needs to be researched, in conducting research and in achieving impact from research results. Universities are under increasing pressure to co-create useful knowledge with the wider community, emphasizing the need for Mode Two (Gibbons et al., 1994) approaches to developing knowledge in the context of application and to take a leading role in Mode Three innovation ecosystems (Harkins and Kubik, 2006; Carayannis and Campbell, 2012). The Triple Helix model is based on the idea that innovation requires close cooperation between universities, industry and government (Etzkowitz, 2003; 2008; 2011), but the engagement of academic researchers in more business-related activities can be challenging (Tuunaien and Knuuttila, 2009). While funding systems have been reformed over some time to emphasize commercial potential and societal relevance (Benner and Sandstrom, 2000), society is not convinced that the performance of universities is meeting the need for relevance (Ellson, 2009). The continuing literature on the gap between research and practice suggests that effective collaboration still has some way to go in many fields (For example: Shafran et al., 2009 [Psychology]; Braun and Hadwiger, 2011 [Food Science]; Earles-Vollrath, 2012 [Education]; Grimshaw et al., 2012 [Health]).

This paper considers the literature on co-creation and in particular, the theoretical debate that has taken place over the last nine years around Service-Dominant Logic (Vargo and Lusch, 2004; $2008 ; 2011)$. The objective of the paper is to demonstrate how the theoretical ideas of ServiceDominant Logic (S-D logic) can usefully be applied to innovation through collaboration between university, industry and government. The aim is to provide a framework that will improve understanding of co-creation in Triple Helix context and to make some recommendations for further research

The effective application of co-creation theory is of crucial importance to the UK economy and society. The competitiveness of UK business is an ongoing concern for the government. Competitive businesses need to be innovative (Porter and Ketels, DTI economics paper No. 3, 2003; Wilson Report, 2012) and innovation requires co-creation at all levels. In the current intensely competitive 
global economy this is of prime importance for economic performance. In the social sphere, responsiveness to research led policy initiatives requires collaboration with service users and communities.

\section{Co-creation theory and practice}

There is a growing interest in co-creation, from both the practitioner and academic communities. Broadly, co-creation refers to the processes by which two or more parties collaborate, or participate, in creating value for themselves or others. The assumption behind co-creation is that there will be a benefit through the involvement of the relevant parties in developing a product/service/initiative. For example, the services marketing literature has for some time highlighted the significance for service suppliers of utilising customer resources (Bitner et al., 1997) and the emergence of the internet has provided new opportunities to harness these (Prahalad and Ramaswamy, 2000). Co-creation is said to be becoming the prevalent approach to innovation for many companies (Bilgram et al., 2011). It is no coincidence that the interest in co-creation has coincided with technological developments, such as Web Two (Rossi, 2011). The emergence of social networks allows companies, such as Unilever, to listen to customers "talking" to each other and to test out new product ideas, through exposing them to the scrutiny of customers on-line. However, co-creation can take many forms and its use is not confined to large consumer companies or exclusively on the web. A review of studies from several disciplines: innovation; strategy; management; marketing and information technology shows the increasing importance of various forms of collaborative innovation (Greer and Lei, 2012). The innovation literature demonstrates this evolution of thinking. Internally oriented, centralised approaches to research and development are becoming obsolete, because useful knowledge has become widespread. Open innovation requires the integration of ideas expertise and skills from outside the organisation (Chesborough, 2003) in order to strengthen internal competencies and accelerate the innovation process in the company (Chesborough, 2006; Von Hippel and Euchner, 2013). While open innovation was originally linked to new product development and business-model change in large companies, the latest perspective can be seen to be far wider, encompassing services, process, management practices and competencies and requiring a more strategic approach (Vanhaverbeke, 2013). In the Triple Helix innovation is defined as "the reconfiguration of elements into a more productive combination" (Etzkowitz, 2008, p4), 
and is a societal issue, including the creation of organisational arrangements that enhance the innovation process.

The theoretical understanding of co-creation has been enhanced by the work on S-D logic (Vargo and Lusch, 2004, 2008, 2011). S-D logic challenges the dominant logic of exchange of the last 200 years (goods-dominant logic [G-D logic]), based on embedded value, where the end point of a transaction is conceptualized as the provision of a product or service (Ballantyne, and Varey, 2008). In S-D logic Vargo and Lusch (2004) argue that increasingly markets have shifted away from the exchange of tangible goods towards the exchange of intangibles, specialized skills and knowledge and processes. Fundamental to S-D logic is the contention that value is not simply created by the supplier and passed onto the customer. The supplier cannot create value unilaterally rather it is a perception on the part of the customer and is co-created (Vargo and Lusch, 2004). While the work on service-dominant logic (S-D logic) initially emerged in the marketing field (Vargo and Lusch, 2004), the ideas can be seen to be highly pertinent in understanding exchanges and interactions between parties involved in collaboration across a number of different areas.

The contention of this paper is that S-D logic provides a lens that may be usefully used to view the process of knowledge co-creation between academics, practitioners, government, shareholders and other stakeholders. Interestingly, there are a number of parallels between G-D logic/S-D logic and the Mode One/Mode Two research approaches outlined by Gibbons, et al., (1994). G-D logic can be seen in Mode One research, which emphasizes problems that are set and solved in a context governed by the largely academic interests of a specific community. Mode Two approaches, on the other hand, where knowledge is created in an interactive way in the context of application (Gibbons, et al., 1994), represent value in use and are more in line with S-D logic. The idea that value is co-created between the supplier and the customer emphasizes interactivity between the two parties (Ballantyne and Varey, 2006; Gronroos, 2011; Ford, 2011) in the same way that Mode Two research requires interaction between those involved in discovery and those involved in application. Interactivity is also emphasized in the Triple Helix literature (Lundberg, 2013; Steiber and Alänge, 2013). S-D logic suggests that as authority moves away from producer to consumer, a command and control approach will no longer work (Fisher and Smith, 2011), suggesting the need for two-party centricity, that simultaneously looks at both suppliers and customers (Gummesson, 2011), or even multi-party centricity, considering networks of actors (Ford, 2011). S-D logic therefore 
challenges the conventional distinction between consumer and producer; in the same way that Mode Two research emphasizes heterogeneity in terms of the sites involved in knowledge production. The literature on Mode Three takes an even broader view, emphasizing the importance of the knowledge society as driver of innovation (Marcovich and Shinn, 2011; Carayannis, Barth, and Campbell, 2012) and in respect to this, learning enhances personal capital (Harkins and Kubik, 2006). Taking this perspective, the university might be seen as a service provider contributing to the experience economy (Pine and Gilmore, 1999) through building the creative capacity of society (Pink, 2005). Again S-D logic has a contribution to make, as an explanation of the provision of service (Vargo and Lusch, 2008).

\section{The core elements of co-creation}

The debate around S-D logic has stimulated much discussion around resource integration, interaction and value creation. These three areas are all pertinent in considering the co-creation of knowledge within the Triple Helix and will be discussed in more detail below. The first area relates to understanding the nature of the resources provided by all the parties involved and the process through which they are integrated. The second area relates to interaction. This is the sphere in which value is created. The third and most complex area relates to how value is perceived by different parties. Value is considered to be determined individually and therefore perceptions of value will be subject to multiple perspectives and may change over time. Consideration of each of these areas leads to a suggestion for a research agenda of relevance for the Triple Helix. A model of co-creation, based on these three areas is then proposed leading to a suggestion for a fourth research agenda.

\section{Resource Integration}

Co-creation, whether through value in use or joint involvement in value generation, involves a process of resource integration. This is the means through which co-creation of value is achieved. The emphasis of S-D logic on the resources of both supplier and customer provides an interesting parallel with the established resource based view (RBV) which emphasizes the resources possessed by firms in driving their performance (Wernerfelt, 1984). RBV is firmly rooted in the idea of resources as being possessed by firms and relating to a firm's overall core competences (Peteraff, 1993). Sustainable competitive advantage is dependent on the rarity and value of the resources that a firm 
can draw on (Prahalad and Hamel, 1990; Barney, 1991). In contrast S-D logic stresses the resources possessed by both the customer and supplier and indeed all the actors involved and the way the resources are utilized at the point of interaction between those involved. This raises an interesting point in relation to the way that new knowledge (innovation) can be co-created by the different stakeholders in the Triple Helix. What resources are provided by the different parties involved and how are they integrated in the process of knowledge creation? A useful idea in S-D logic is the distinction made between the two types of resources that figure in creating value. These are termed Operand and Operant resources. Operand resources, such as raw materials, are "... resources on which an operation or act is performed to produce an effect" (Vargo and Lusch 2004, p. 2). These require input from an active agent in order to realize value (Arnould et al., 2006; Lusch et al., 2008). Operant resources provide this active agent. It is operant resources that drive value creation, and hence: "Operant resources constitute the fundamental source of competitive advantage" (Vargo and Lusch 2008, p.6). The strong tendency in the developing body of literature on the subject is to assume operant resources to be synonymous, in broad terms, with knowledge and skills (Vargo and Lusch 2004; King and Grace 2008; Layton 2008; Vargo and Lusch 2008). However, Ballantyne and Varey (2006) usefully make a distinction between tacit and explicit knowledge. Tacit knowledge consists of "know-how or competencies gained through observation, imitation and mutual experience...", whereas "...explicit knowledge is media-based and can be digitized, duplicated and circulated." (Ballantyne and Varey, 2006 p. 340). Tacit knowledge can be seen to be a particularly significant operant resource in knowledge co-creation, because it may be more likely to come from the practitioner than the academic community.

The question of how and when resource integration takes place relates to a fundamental point regarding the translation of research into practice. Is the issue one of knowledge transfer or of knowledge production (Van De Ven and Johnson, 2006; Shapiro et al., 2007)? The knowledge transfer approach suggests that the researcher needs to be effective in knowledge management and dissemination. Knowledge management requires a strategy for getting the right knowledge to the right people at the right time (Kingston, 2012). This can be very demanding, to take an example, in the field of Information Systems there are over 500 journals and researchers face ever increasing complexity in deciding where to place their research (Holsapple, 2009). Advances in digital communications provide new opportunities (Thelwall and Harries, 2004; Bourne and Chalupa, 2008; Shiovitz et al., 
2011), but also new challenges in terms of information overload (Katakis et al., 2009). Effective dissemination of knowledge may also involve a lot of hard work in translating knowledge (Corcoran, 2006; Lafreniere and Cox, 2012), involving communication skills that may not be second nature to many academics (Landfried, 1989). Proponents of co-production of knowledge would point to some of the challenges in knowledge transfer, such as lack of face-to-face contact, lack of trust and cultural differences (Braun and Hadwiger, 2011), as stemming from a lack of recognition of the social components of knowledge creation (Nonaka, 1994; Nowotny et al., 2001). The need for integrating tacit knowledge, from the context of application, with explicit knowledge from the research process suggests an imperative to consider how these different resources can be integrated in the research context, suggesting:

\section{Research Agenda One - To explore the nature of the resources employed by Triple Helix partners in co-creating knowledge and to understand how these resources can be integrated most effectively in different co-creation contexts.}

\section{Interaction}

In the commercial sphere, addressed by Service-Dominant logic, interaction between customers and suppliers is crucial in creating value for customers (Ballantyne and Varey, 2006). Value cannot be created unilaterally by the supplier (Vargo and Lusch , 2008). All a supplier can do is to make propositions that have potential value for their customers (Ballantyne et al., 2011) But in the joint sphere of interaction the supplier may also get the opportunity to engage in the customer's value creation process (Gronroos and Voima, 2013). Customers have a range of interactions, of course, including those with other customers and may be highly discriminating in the interactions that they are prepared to have and so the quality of the interaction (Prahalad and Ramaswamy, 2004) and the experience of the interaction (Ramaswamy, 2011) is important . Extensive interaction between researchers and practitioners is implied in the argument for engaged scholarship (Van De Ven, 2007). The Triple Helix literature also recognises the fundamental importance of interaction in research: "The Triple Helix thesis postulates that the interaction in university-industry-government is the key to improving the condition for innovation in a knowledge-based society" (Etzkowitz, 2003, p292). However, collaboration with practitioners requires dealing with human processes and this can be very resource intensive (Mesny and Mailhot, 2012) and complex (Antonacopoulu et al., 2011). For 
example, in the field of psychotherapy, Castonquay (2011) suggests the need to interact across different theoretical orientations, scientific fields, professional experiences and epistemological views. In the UK, the requirement of research councils for grant applicants to include a section on 'Pathways to impact', suggests researchers need to have a wide social network (Williams, 2012), but the quality of interaction in these networks may vary widely. The number of links through the worldwide web is not necessarily a good measure of dissemination or impact (Thelwall and Harries, 2004). There is a need to consider the best interaction practices (Echeverri and Skalen, 2011) supporting the argument for more research in this area:

\section{Research Agenda Two - To explore current modes of interaction between Triple Helix partners and their effectiveness in enhancing co-creation of knowledge.}

\section{The perception of value}

Value is a complicated phenomenon. Khalifa (2004) argues that value is one of the most misused concepts in the social sciences. In traditional economic theory value is held to be about utility, the utility provided by the product or service against the price paid (Zeithaml, 1988; Afuah, 2002). Consumers are considered to be rational and make choices to maximise utility (Chiu et al., 2005). S-D logic is concerned with the perception of value, as a phenomena that is “... idiosyncratic, experiential, contextual and meaning laden" (Vargo and Lusch, 2008, p7). Understanding perception of value brings in the numerous intangible and emotional elements involved (Holbrook, 1986; de Ruyter et al., 1997; Mathwick et al., 2001; Sweeney and Soutar, 2001). Rather than being a characteristic of objects, value emerges from the subject's interaction with the object (Holbrook 1996, 2005). Vargo and Lusch (2008) conceptualise that value is always co-created and is determined at the point of using, consuming or experiencing the outcomes of service. Value is a perception that is always uniquely and phenomenologically determined by the beneficiary (Vargo and Lusch, 2004). Therefore the supplier cannot create value on its own, but only offer value propositions. Such propositions have no intrinsic value and require the application, or integration, of customer resources to realise their value.

Value realisation may be highly complex in some contexts. For example in business-tobusiness (B2B): "Value for a business customer does not emerge from one resource - the core product - only, but from the whole spectrum of supplier-customer interactions that support a 
successful use of this core resource." (Gronroos, 2011, p. 240). Furthermore, as well as being episodic, value needs to be seen as reciprocal amongst the actors involved (Ballantyne et al., 2011; Ford, 2011) and needs to be understood in relation to all stakeholder domains (Frow and Payne, 2011). Therefore value realisation may involve a range of perspectives from the actors involved and in many cases takes place over an extended time period, with the evaluation of value varying at different stages in the process of realisation.

Again these ideas can be seen to be applicable to the sphere of knowledge co-creation. Mode Two knowledge production happens in a social context amongst diverse communities (Nowotny et al., 2001). The impact of research will be determined by the perception of the user community of the value of the findings and this perception will be partly determined by interactions between the communities involved in knowledge production and use. Therefore understanding the complexity of how value is realised is important. The nature of value realisation will vary greatly in relation to different subject fields and practitioner contexts. The most obvious example of value realisation is commercialisation whether through direct or indirect adoption of a new technology by industry or through a spin-out company. Technology transfer may work through user communities (Cummings and Teng, 2003; Oswald, 2005; Shanthy, 2011) or as part of regional development programmes (Hussle et al., 2010). Another form of value realisation may be in creating behaviour change in community contexts (For example: Kanouse et al., 1995; Dietrich et al., 2003; Russell, 2007) or changing the practice of professional practitioners (Ousley et al., 2010) or changing public policy (Kerner and Hall, 2009). Value may be realised at many levels and over extended time periods and hence will be perceived in varying ways by different stakeholders and over time. Hence:

Research Agenda Three - To understand how the different Triple Helix partners perceive the value that can be achieved through co-creation and what value propositions will motivate potential partners.

\section{A model of co-creation}

The assertion in S-D logic that the supplier cannot create value unilaterally recognizes that there are a range of actors that bring their own resources into play in the co-creation process. In making this happen there needs to be a value proposition that is motivating for all the parties in the Triple Helix to get involved in the co-creation process. The process then involves interaction and 
resource integration, resulting in a modification of the resources (new knowledge) of all those involved. This is summed up in Figure 1.

\section{Figure 1 The Co-creation Process}

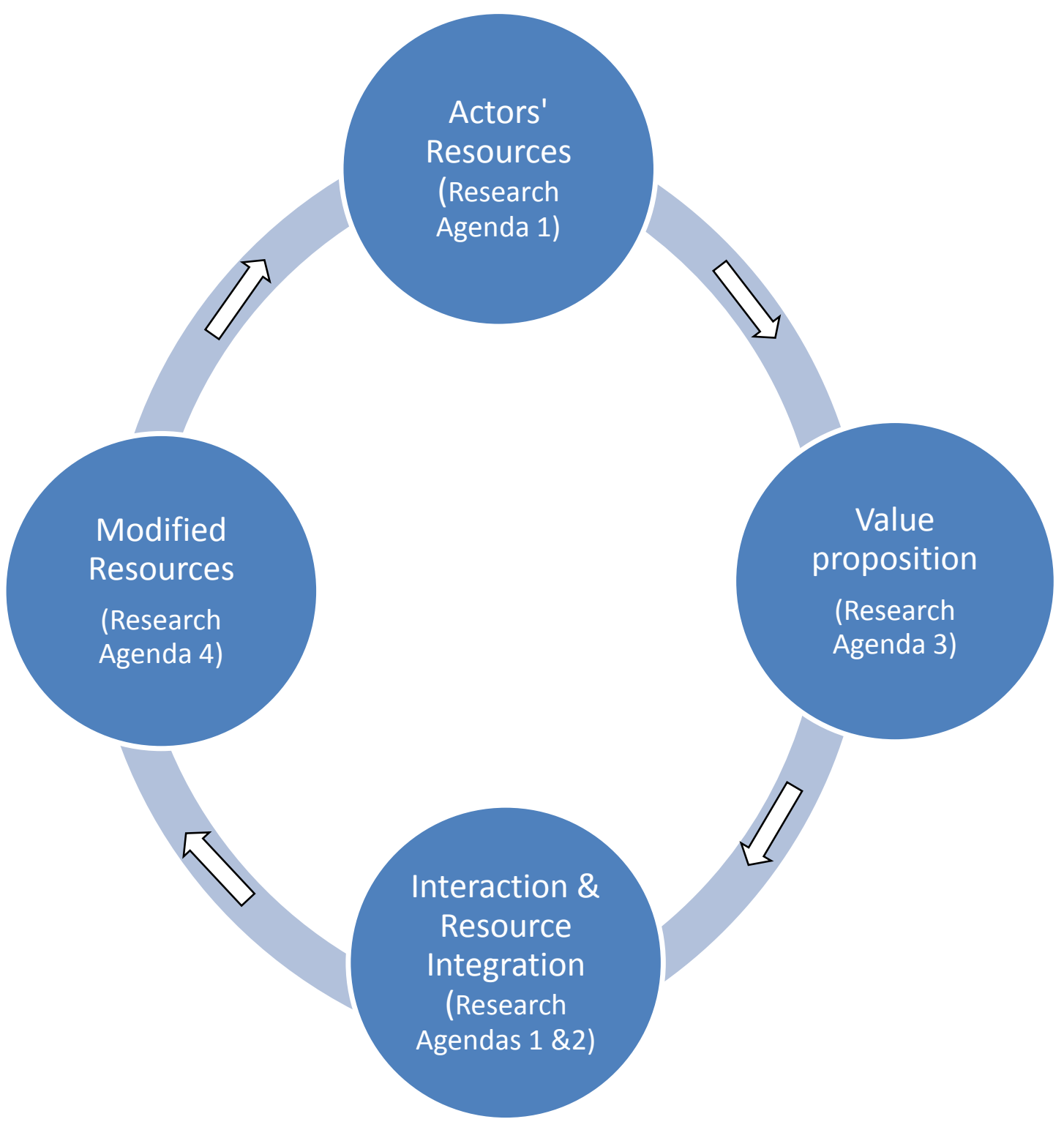

Source: Adapted from Hilton et al., (2013)

The model suggests that as part of the process the resources of the actors involved will be modified (hopefully enhanced). This suggests a further research area:

Research Agenda Four - To understand how the different Triple Helix partners' resources are modified through the co-creation process in different contexts. 


\section{Implications}

The contention of this paper is that S-D logic provides new perspectives that can usefully be applied to the creation of new knowledge between the stakeholders in the Triple Helix communities. Similarities can be discerned between Mode One approaches to knowledge creation and G-D logic and Mode Two/Mode Three approaches and S-D logic. Applying S-D logic to the research process takes the perspective that the value of any research project is only realised when the research is used in some way. Most interestingly, S-D logic has stimulated a discussion relating to various elements of co-creation worthy of further research in relation to the co-creation of knowledge. These are firstly, the recognition that all parties bring their particular resources into the process and that co-creation involves resource integration that will modify the resources of all those involved. Secondly, that interaction is a fundamental part of the process, providing the opportunity for parties involved to influence the creation of value. Thirdly, the perceptions of the value of the research may be very different between the parties involved.

A fundamental point in the Triple Helix literature is that research problem definition comes from outside the university research community (Etzkowitz, 2003). A central idea in S-D logic is that resource integration is the means through which value is co-created (Vargo and Lusch, 2011) and this provides a potential framework to consider the role of the stakeholders in the research process, as suggested in Research Agenda One. What resources do different actors contribute to the process? Where are the most significant operant resources situated in the network? How can different types of knowledge be used effectively? Where does the best tacit knowledge of practice reside? Co-creation in research requires collaboration with users from an early stage. The perspective taken here is that knowledge creation is a social process (Nonaka, 1994; Amabile et al., 2001; Nowotny et al., 2001) and that knowledge is socially constructed in communities (Lang, 2001). This suggests that cocreated research needs to get through the "double hurdle" of both addressing a knowledge gap in the traditional sense and addressing a subject that is important to a significant group of users (Pettigrew, 1997). This puts a focus on the different user groups for the research and on how they access and utilise the findings. Value may be realised by different groups over varying time periods and in different ways. Users may include:

- Other academics researching/teaching in the same field 
- Professionals/consultancies whose reputation rests on them having access to the latest knowledge

- Entrepreneurs and others involved in the commercialisation of new ideas

- Anyone applying research findings at a local/community level

- Policy-making bodies

User involvement in the research process requires that the users are motivated enough to become involved. Users need to see a value proposition that interests and engages them from an early stage in the research process (Research Agenda Three). For the researcher or research team this presents a challenge, as suggested in Research Agenda Two. How do they identify those who would perceive potential value in their research? And having identified potential users, how do they set up meaningful interactions with users? In some cases joining an existing practitioner network may be possible. While in others it may be necessary to set up new network initiatives. To some extent it is incumbent on individual researchers to establish their own networks as they develop their career. However, while academic success has traditionally relied on involvement in academic networks establishing and developing effective wider networks has been outside the remit of many academics. While the technological infrastructure for electronic networking is now well established (Song et al., 2007), meaningful networks between academics and practitioners can take a lot of time and effort to set up and can be difficult to sustain (Hughes et al., 2011). Therefore, more encouragement, resources and support is needed in this area and many universities are now recognising the need to give professional support to individuals and groups of researchers in identifying potential users and in setting up networks.

As much as anything, recognition of the resources that users can bring to the research process implies a change of mind-set about the research process from Mode One, where problems are set and solved by the academic community to Modes Two and Three, where this happens in the context of application and the wider society. Traditionally the emphasis for academics in conducting and disseminating research has been the academic group, through journal publication, conference papers and citation. However, there is a growing recognition that this narrow focus results in missed opportunities (Wilson Review of Business-University Collaboration, 2012). The push to demonstrate wider impact from research is reflected in the inclusion of impact case studies in the UK Research Evaluation Framework (REF) 2014 and in the requirement to include justification of impact in UK and 
European grant applications. However, collaboration between businesses and universities is difficult owing to differences in values and cognitive styles (Viale, and Etzkowitz, 2010). A culture change, such as this, will take time to emerge and will require a sustained effort at many levels. Many existing academics, who have established their careers in a largely Mode One context, may need to be persuaded, motivated and supported in new ways if they are going to co-create with users, as part of an interactive and collaborative process. Research Agenda Four relates to this in relation to how far the resources of the actors involved are modified, as a result of that collaboration. Culture change is also required on the part of users of research, as well as the academic research community. In many fields potential users do not understand the value that academic research can add and are not willing to give their own resources (time and money) towards collaborative work. In Figure 1 we suggest that the co-creation process leads to modification of the resources of users (hopefully enhancement) which will become a virtuous circle. The more it happens the more user groups will recognise the potential value in taking part.

The co-creation model (Hilton et al., 2013), featured in Figure 1, could be directly applied to regional Triple Helix type initiatives, as a conceptual framework to analyse the development and operation of consensus spaces (neutral ground where different actors can come together to generate and agree new ideas to support) and innovation spaces (where innovation and societal needs come together to realise the goals articulated in the consensus phase), as put forward by Etzkowitz (2008). This type of analysis could potentially further our understanding of how to make the Triple Helix work effectively in practice.

\section{Conclusions}

The Triple Helix model proposes an extension of the traditional research and teaching mission of universities to play a leading role in innovation in conjunction with other key stakeholders. However, creating a more effective and collaborative research culture is highly challenging. It is now nearly 20 years since Gibbons et al. (1994) argued for a greater emphasis on research in the context of application and yet there is still a long way to go in matching the needs of business and the community with the outputs of research (Wilson Review of Business-University Collaboration, 2012). While open source publication may make academic journal articles more generally available and new technology provides many novel opportunities for disseminating knowledge, there remains the 
problem that academic papers may well not be read by busy practitioners. One challenge is that effective interaction with different user groups requires time and resources and professional communication skills that may not be available to the research team. Another challenge is that of providing appropriate metrics to judge success in knowledge exchange activities. Traditional measures of academic achievement, such as quality of publications and citations are relatively straightforward, but are no longer sufficient. However, measuring wider impact is very challenging across different research fields, contexts and time-periods.

However, contemporary thinking would suggest that this is more than just a communication problem. What is needed is a better understanding of how different actors in the process create their own value in use. New thinking on how value is perceived, as epitomised in S-D logic, has the potential to stimulate new initiatives in working with research users to co-create value in the same way that commercial organisations are learning how to co-create with their customers. Developments in technology, for networking, provide far more opportunities for this than ever before. However, it requires new skill sets for researchers and also the motivation on all sides to contribute to the cocreation process. Further research on co-creation in the specific context of academic research projects, across a range of fields would be useful in providing evidence of successful practice. This paper suggests a number of research agendas that are derived from the main debates in S-D logic relating to resource integration, interaction, perception of value and resource modification. Furthermore, a model of the co-creation process is proposed that encompasses these four research agendas and provides a conceptual framework to analyse Triple Helix initiatives.

\section{References}

Afuah, A. (2002) 'Mapping Technological Capabilities into Product Markets and Competitive Advantage: The Case of Cholesterol Drugs', Strategic Management Journal, 23, 2, pp. 171-9.

Amabile, T. M. Patterson, C. Mueller, J. Wojcik, T. Odomirok, P.W. Marsh, M. and Kramor, S.J. (2001) 'Academic Practitioner Collaboration In Management Research: A Case Of Cross-Profession Collaboration', Academy of Management Journal, 44, 2, pp. 418-431.

Antonacopoulou, E. Dehlin, E. and Zundel, M. (2011) 'The Challenge of Delivering Impact: Making Waves Through the ODC Debate', The Journal of Applied Behavioral Science, 47, 1, pp. 33-52.

Arnould, E. J., Price L. L. and Malshe, A. (2006) 'Toward a Cultural Resource-Based Theory of the Customer', iln Lusch, R. F. and Vargo, S. L. (eds.), The Service-Dominant Logic of Marketing: Dialog, Debate and Directions, ME Sharpe, Armonk NY, pp. 320-333.

Ballantyne, D. and Varey, R. (2006) 'Creating value-in-use through marketing interaction: the 
exchange logic of relating communicating and knowing', Marketing Theory, 6, p.335.

Ballantyne, D. and Varey, R.J. (2008) 'The service-dominant logic and the future of marketing', Journal of the Academy of Marketing Science, 36, pp 11-14.

Ballantyne, D. Williams, J. and Aitken, R. (2011) 'Introduction to service-dominant logic: From propositions to practice', Industrial Marketing Management, 40, 2, pp. 179-180.

Barney, J.B. (1991) 'Firm resources and sustained competitive advantage', Journal of Management, 17, pp. 99-120.

Benner, M. and Sandstrom, U. (2000) 'Institutionalizing the triple helix: research funding and norms in the academic system', Research Policy, 29, pp. 291-301.

Bilgram, V. Bartl, M. and Biel, S. (2011) 'Getting Closer to the Consumer- How Nivea Co-Creates New Products', Marketing Review St Gallen, 1, pp. 34-40.

Bitner, M. J. Faranda, W. T. Hubbert, A. R. and Zeithaml, V. A. (1997) 'Customer Contributions and Roles in Service Delivery', International Journal of Service Industry Management, 8, 3, pp. 193-205.

Bourne, P. E. \& Chalupa, L. M. (2008) 'A new approach to scientific dissemination', Materials Today. 11,6, p. 48.

Braun, S. and Hadwiger, K. (2011) 'Knowledge Transfer from research to industry (SMEs) - An example from the food sector', Trends in Food Science \& Technology, 22, 1, pp. S90-S96.

Carayannis, E. Barth, T. Campbell, D. (2012) 'The Quintuple Helix innovation model: global warming as a challenge and driver for innovation', Journal of Innovation and Entrepreneurship, 1, 1, pp.1-12.

Carayannis, E. and Campbell, D. (2012) Mode 3 Knowledge Production in Quadruple Helix Innovation Systems: 21st-Century Democracy, Innovation, and Entrepreneurship for Development (Springer Briefs in Business, Volume 7), Springer, NY.

Castonguay, L.G. (2011) 'Psychotherapy, psychopathology, research and practice: Pathways of connection and integration', Pyschotherapy Research, 21, 1, pp. 125-140.

Chesborough, H. (2003) 'The era of open innovation', MIT Sloan Management Review, Spring2003, 44, 3,pp. 35-41.

Chesbrough, H. (2006) Open innovation: The new imperative for creating and profiting from technology, Harvard Business Press, Boston MA.

Chiu, H. C., Hsieh, Y.C., Li, Y.C. and Lee, M. (2005) 'Relationship Marketing and Consumer Switching Behavior', Journal of Business Research, 58, 12, pp. 1681-9.

Corcoran, M. (2006) 'Dissemination or Knowledge Translation?', The American Journal of Occupational Therapy, 60, 5, pp.487-488.

Cummings, J. and Teng, B. (2003) 'Transferring R\&D knowledge: the key factors affecting knowledge transfer success', Journal of Engineering and Technology Management, 20, 1, pp.39-68.

de Ruyter, K., Wetzels, M., Lemmink, J. and Mattsson, J. (1997) 'The Dynamics of the Service Delivery Process: A Value-Based Approach', International Journal of Research in Marketing, 14, 3 , pp. 231-43.

Dietrich, A. J. Oxman, T.E. and Williams, J.W. (2003) 'Dissemination to community-based practices', Journal of Psychosomatic Research, 55, 2, pp.111- 122.

Earles-Vollrath, T. L. (2012) 'Research to Practice: Closing the Gap', Intervention in School and 
Clinic, 47, 3, pp.135-138.

Echeverri, P. and Skalen, P. (2011) 'Co-creation and co-destruction: A practice-theory based study of interactive value formation', Marketing Theory, 11, 3, pp. 351-373.

Ellson, T. (2009) 'Assessing contribution of research in business to practice', Journal of Business Research, 62, pp. 1160-1164.

Etzkowitz, H. (2003) 'Innovation in Innovation: The Triple Helix of University-Industry-Government Relations', Social Science Information, 42, 3, pp. 293-337.

Etzkowitz, H. (2008) The Triple Helix: University-Industry-Government Innovation in Action, Routledge, Oxon.

Etzkowitz, H. (2011) 'Normative change in science and the birth of the Triple Helix', Social Science Information, 50, 3-4, pp. 549-568.

Fisher, D. and Smith, S. (2011) 'Co-creation is chaotic: What is means for marketing when no one has control', Marketing Theory, 11, 3, pp. 325-350.

Ford, D. (2011) 'IMP and service-dominant logic: Divergence, convergence and development', Industrial Marketing Management, 40, 2, pp. 231-239.

Frow P. and Payne, A. (2011) 'A stakeholder perspective of the value proposition concept', European Journal of Marketing, 45, 1/2, pp. 223-240.

Gibbons, M. Limoges, C. Nowotny, H. Schwartzman, S. Scott, P. and Trow, M. (1994) The new production of knowledge. The Dynamics of Science and research in Contemporary Societies, Sage, London.

Greer, C. and Lei, D. (2012) 'Collaborative Innovation with Customers: A Review of the Literature and Suggestions for Future Research', International Journal of Management Reviews, 14, 1, pp. 63-84.

Grimshaw, J. M., Eccles, M.P. Lavis, J.N. Hill, S.J. and Squires, J.E. (2012) 'Knowledge translation of research findings', Implementation Science, 7, May Issue, pp. 1-17.

Gronroos, C. (2011) 'A service perspective on business relationships', Industrial Marketing Management, 40, 2, pp 240-247.

Gronroos, C. and Voima, P. (2013) 'Critical service logic: making sense of value creation and cocreation', Academy of Marketing Science, 41, 2, pp. 133-150.

Gummeson, E. (2011) '2B or not 2B: That is the question', Industrial Marketing Management, 40, 2, pp. 190-192.

Harkins,A. and Kubik, G. (2006) 'Leapfrogging toward the "singularity": innovative knowledge production on market-driven campuses', On the Horizon, 14, 3, pp.99 - 107.

Hilton, T. Hughes, T. and Chalcraft, D. (2012) 'Co-creation: resource integration and value realisation', Journal of Marketing Management, 28, 13-14, pp. 1504-1519.

Holbrook, M. (2005) 'Customer value and autoethnography: subjective personal introspection and the meanings of a photograph collection', Journal of Business Research, 58, pp. 45-61.

Holbrook, M.B. (1986) 'Emotion in the Consumption Experience: Toward a New Model of the Human Consumer', in R.A. Peterson (ed.) The Role of Affect in Consumer Behavior: Emerging Theories and Applications, Lexington Books, Lexington, MA., pp. 17-52.

Holbrook, M.B. (1996) ‘Customer Value - A Framework for Analysis and Research', Advances in 
Consumer Research, 23, 1, pp. 138-42.

Holsapple, C. W. (2009) 'A New Map for Knowledge Dissemination Channels', Communications of the ACM - Being Human in the Digital Age, 52, 3, pp. 117-125.

Hughes, T. Bence, D. Grisoni, L. O’Regan, N. and Wornham, D. (2011) 'Scholarship That Matters: Academic/Practitioner Engagement in Business \& Management', Academy of Management Learning and Education, 10, 1, pp. 40-57.

Hussle, C. Picard, F. and Tang, M. F. (2010) 'Taking the ivory from the tower to coat the economic world: Regional strategies to make science useful', Technovation, 30, 9/10, pp.508-518.

Kanouse, D. E. Kallich, J. D. and Kahan, J. P. (1995) 'Dissemination of effectiveness and outcomes research', Health Policy, 34, 3, pp.167-192.

Katakis, I, Tsoumakas, G. Banos, E. Bassiliades, N. and Vlahavas, I. (2009) 'An adaptive personalized news dissemination system', Journal of Intelligent Information Systems, 32, 2, pp. 191212.

Kerner, J. F. and Hall, K. L. (2009) 'Research Dissemination and Diffusion: Translation Within Science and Society', Research on Social Work Practice, 19, 5, pp. 519-530.

Khalifa, A.S. (2004) 'Customer Value: A Review of Recent Literature and an Integrative Configuration', Management Decision, 42, 5/6, pp. 645-66.

King, C. and Grace, D. (2008) 'Internal branding: Exploring the employees' perspective', Brand Management, 15, 5, pp.358 - 372.

Kingston, J. (2012) 'Choosing a Knowledge Dissemination Approach', Knowledge and Process Management, 19, 3, pp. 160-170.

Lafrenière, D. and Cox, S. (2012) 'Means of Knowledge Dissemination: Are the Café Scientifique and the Artistic Performance Equally Effective?', Sociology Mind, 2, 2, pp.191-199.

Landfried, S. E. (1989) 'Strategies for Effective Information Dissemination in a 'High-tech' Age', Environmental Conservation, 16, 2, pp.123-128.

Lang, J. C. (2001) 'Managerial concerns in knowledge management', Journal of Knowledge Management, 5, 1, pp. 43-57.

Layton, R. A. (2008) 'The search for a dominant logic: A macromarketing perspective', Journal of Macromarketing, 28, 3, pp.215 - 227.

Lundberg, H. (2013) 'Triple Helix in practice: the key role of boundary spanners', European Journal of Innovation Management, 16, 2, pp.211 - 226

Lusch, R.F. Vargo, S.L. and Wessels, G. (2008) 'Toward a conceptual foundation for service science: Contributions from service-dominant logic', IBM Systems Journal, 47, 1, pp.5-14.

Marcovich, A. and Shinn, T. (2011) 'From the Triple Helix to a Quadruple Helix? The Case of Dip-Pen Nanolithography', Minerva, 49, 2, pp 175-190.

Mathwick, C., Malhotra, N. and Rigdon, E. (2001) 'Experiential Value: Conceptualization, Measurement and Application in the Catalog and Internet Shopping Environment', Journal of Retailing, 77, 1, pp. 39-56.

Mesny, A. and Mailhot, C. (2012) 'Control and traceability of research impact on practice: reframing the 'relevance gap' debate in management', Management, 15, 2, pp. 180-207. 
Nonaka, I. (1994) 'A dynamic theory of knowledge creation', Organization Science, 5, 1, pp. 14-37.

Nowotny, H. Scott, P. and Gibbons, M. (2001) Re-Thinking Science: Knowledge and the Public in an Age of Uncertainty, Blackwell, Oxford.

Oswald, A. (2005) 'Striga control—technologies and their dissemination', Crop Protection, 24, 4, pp. 333-342.

Ousley, A. L. Swarz, J. A. Milliken, E. L. \& Ellis, S. (2010) 'Cancer Education and Effective Dissemination: Information Access is not Enough', Journal of Cancer Education, 25, 2, pp.196-205.

Peteraff, M. (1993) 'The cornerstones of competitive advantage: A resource-based view', Strategic Management Journal, 14, pp. 179-191.

Pettigrew, A.M. (1997) 'The double hurdles for management research', in T. Clarke Ed. Advancement in organizational behaviour: Essays in honour of J.S. Pugh (277-296), Dartmouth Press, London.

Pine, J. and Gilmore, J. (1999) The Experience Economy: Work Is Theatre and Every Business a Stage, Harvard University Press, Boston MA.

Pink, D. (2005) A whole new mind : moving from the information age to the conceptual age, Allen \& Unwin, Crow's Nest, N.S.W.

Porter and Ketels, (2003) DTI economics paper No. 3.

Prahalad, C. and Ramaswamy, V. (2004) 'Co-creation Experiences: The Next Practice In Value Creation', Journal of Interactive Marketing, 18, 3, pp. 5-14.

Prahalad, C.K. and Hamel, G. (1990) 'The core competence of the corporation', Harvard Business Review, May-June, pp 79-91.

Prahalad, C.K. and Ramaswamy, V. (2000) 'Co-opting Customer Competence', Harvard Business Review, 78 January, pp. 79-90.

Ramaswamy, V. (2011), It's about human experiences.....and beyond, to co-creation, Industrial Marketing Management, Vol 40 No 2, pp. 195-196.

Rossi, C. (2011) 'Online consumer communities, collaborative learning and innovation', Measuring Business Excellence, 15, 3, pp. $46-62$.

Russell, E. (2007) 'eHealth Evaluation and Dissemination Research', American Journal of Preventive Medicine, 32, 5, pp. S119-29.

Shafran, R. Clark, D.M. Fairburn, C.G. Arntz, A. Barlow, D.H. Ehlers, A. Freeston, M. Garety, P.A. Hollon, S.D. Ost, L.G. Salkovskis, P.M. JWilliams, .M.G. and Wilson, G.T. (2009) 'Mind the gap: Improving the dissemination of CBT', Behaviour Research and Therapy, 47, 11, pp. 902-909.

Shanthy, T. R. (2011) 'Strategies for Effective Dissemination of Appropriate Technologies to Sugarcane Growers in India', Society for Sugar Research \& Promotion, 13, 4, pp. 354-359.

Shapiro, D. L. Kirkman, B. L. and Courtney, H.G. (2007) 'Perceived Causes And Solutions Of The Translation Problem In Management Research', Academy of Management Journal, 50, 2, pp. 249266.

Shiovitz, S. Ashley, G. Morris, A. Graff, J. Katz, S. and Hawley, S. (2011) 'Dissemination of Qualityof-Care Research Findings to Breast Oncology Surgeons', American Society of Clinical Oncology, 7, 4, pp. 257-262.

Song, M. Berends, H. Van Der Bij, H. and Weggeman, M. (2007) 'The Effect of IT and Co-location on 
Knowledge Dissemination', Journal of Product Innovation Management, 24, 1, pp. 52-68.

Steiber, A. and Alänge, S. (2013) 'The formation and growth of Google: A firm-level triple helix perspective', Social Science Information, 52, 4, pp. 515-538.

Sweeney, J.C. and Soutar, G.N. (2001) 'Consumer Perceived Value: The Development of a Multiple Item Scale', Journal of Retailing, 77, 2, pp. 203-20.

Thelwall, M. and Harries, G. (2004) 'Can personal web pages that link to universities yield information about the wider dissemination of research?' Journal of Information Science, 30, 3, pp. 240-253.

Tuunainen, J. and Knuuttila, T. (2009) 'Intermingling Academic and Business Activities, A New Direction for Science and Universities?' Science, Technology \& Human Values, 34, 6, pp. 684-704.

Van de Ven, A. H. (2007) Engaged Scholarship: A Guide for Organizational and Social Research, Oxford University Press, Oxford.

Van De Ven, A.H. and Johnson, P. E. (2006) 'Knowledge For Theory And Practice', Academy of Management Review, 31, 4, pp. 802-821.

Vanhaverbeke, W. (2013) 'Rethinking Open Innovation Beyond the Innovation Funnel Technology Innovation', Management Review, April, pp. 6-10.

Vargo, S. L. and Lusch, R. F., (2004) 'Evolving to a New Dominant Logic for Marketing', The Journal of Marketing, 68, 1, pp. 1-17.

Vargo, S.L. and Lusch, R.F. (2008) 'Service-dominant logic: continuing the evolution', Journal of the Academy of Marketing Science, 36, pp 1-10.

Vargo, S. and Lusch, R.F. (2011) 'It's all B2B...... and beyond: Toward a systems perspective of the market', Industrial Marketing Management, 40, 2, pp. 181-187.

Viale, R. and Etzkowitz, H. (Eds) (2010) The capitalization of knowledge: a triple helix of universityindustry-government, Edward Elgar.

Von Hippel, E. and Euchner, J. (2013) 'User innovation', Research Technology Management, May/Jun2013, 56, 3, pp. 15-20.

Wernerfelt, B. (1984) 'A resource-based view of the firm', Strategic Management Journal, 5, pp. 171180.

Williams, G. (2012) 'The disciplining effects of evaluation practices: negotiating the pressures of impact within an ESRC-DFID project', Transactions of the Institute of British Geographers, 37, pp. 489-495.

Wilson, T. (2012) A Review of Business-University Collaboration.

https://www.gov.uk/government/uploads/system/uploads/attachment_data/file/32383/12-610-wilsonreview-business-university-collaboration.pdf

Zeithaml, V.A. (1988) 'Consumer Perceptions of Price, Quality, and Value: A Means-end Model and Synthesis of Evidence', Journal of Marketing, 52, 3, pp. 2-22. 